\title{
EFEKTIVITAS IMPLEMENTASI KEBIJAKAN PENATAUSAHAAN BARANG MILIK NEGARA
}

(Studi pada Balai Litbangkes Banjarnegara)

\author{
Ghonimah Z Ainiyah', Siti Maesaroh² Margono $^{3}$ \\ ${ }^{1,2,3}$ STIE Tamansiswa Banjarnegara \\ eny.wsb@gmail.com
}

\begin{abstract}
The problem raised in this study is the administration of goods that have not gone well because of the gap between the facts in the field and the theory used and with government regulation number 27 of 2014 concerning the management of state/regional property. This study aims to analyze the effectiveness of the implementation of state property administration policies. The location of the research was carried out at the Balai Litbang Kesehatan Banjarnegara office. This research uses qualitative research, informants are selected based on purposive sampling with 6 (six) informants and data collection through interviews, observation and attempts to design and record or take notes on the information. The results of the research that have been analyzed show that there are problems seen from 4 (four) aspects including resources, communication, disposition and bureaucratic structure that have not been maximized in managing state property, so by better understanding state property administration policies will have a significant impact on improving the administration of state property more effectively and efficiently.
\end{abstract}

Keywords: effectiveness, policy, state property, inventory

\section{PENDAHULUAN}

Undang-undang Nomor 17 Tahun 2003 tentang Keuangan Negara beserta Undangundang Nomor 01 Tahun 2004 tentang Perbendaharaan Negara yang kemudian dijabarkan dengan Peraturan Pemerintah Nomor 27 Tahun 2014 tentang Pengelolaan Barang Milik Negara/Daerah merupakan bentuk kongkrit upaya pemerintah khususnya Republik Indonesia dalam penertiban dan pengelolaan barang/aset negara dan daerah. Kemudian diperkuat lagi dengan Peraturan Menteri Keuangan Republik Indonesia Nomor 181/PMK.06/2016 tentang Penatausahaan Barang Milik Negara.

Definisi Barang Milik Negara atau BMN dalam Peraturan Menteri Keuangan Nomor 181 Tahun 2016 Bab I (satu) Pasal 1 (satu) yaitu, semua barang yang dibeli atau diperoleh atas beban anggaran pendapatan dan belanja negara atau berasal dari perolehan lainnya yang sah, sedangkan penatausahaan adalah rangkaian kegiatan yang meliputi pembukuan, inventarisasi, dan pelaporan barang milik negara sesuai dengan ketentuan peraturan perundang-undangan. Sedangkan ruang lingkup kegiatan penatausahaan barang milik negara diantaranya pembukuan yang terdiri atas kegiatan pendaftaran dan pencatatan barang milik negara ke dalam daftar barang, inventarisasi yang terdiri atas kegiatan pendataan, pencatatan dan pelaporan yang terdiri atas kegiatan penyusunan dan penyampaian data dan informasi barang milik negara secara semesteran dan tahunan. Penatausahaan barang milik negara termasuk dalam lingkup keuangan negara yang menuntut adanya pertanggungjawaban, akuntabilitas serta tranparansi.

Kemudian objek penatausahaan barang milik negara meliputi semua barang yang dibeli atau diperoleh atas beban anggaran pendapatan dan belanja negara dan juga semua barang yang berasal dari perolehan lainnya yang sah, meliputi barang yang diperoleh dari hibah/ sumbangan atau yang sejenisnya, barang yang diperoleh sebagai pelaksanaan perjanjian/kontrak, barang yang diperoleh sesuai dengan ketentuan peraturan perundangundangan atau barang yang diperoleh 
berdasarkan putusan pengadilan yang telah memperoleh kekuatan hukum tetap. Penatausahaan barang milik negara yang baik dan benar akan mencegah terjadinya potensi penyimpangan atau penyalahgunaan wewenang, kehilangan aset, kerugian negara, dan sebagainya.

Balai Litbangkes Banjarnegara, merupakan salah satu Unit Pelaksana Teknis Badan Penelitian dan Pengembangan Kesehatan yang merupakan instansi vertikal langsung di bawah Kementerian Kesehatan Republik Indonesia, yang salah satu kegiatan manajerialnya adalah penatausahaan barang milik negara. Dalam menjalankan tugas dan fungsinya Balai Litbangkes Banjarnegara didukung oleh sarana dan prasarana sebagai fasilitas penunjang pekerjaan bagi para pegawai. Sarana dan prasarana tersebut dapat berupa barang/jasa. Barang yang digunakan sebagai fasilitas kerja ini disebut dengan barang milik negara yang pengadaan dan pembeliannya dilakukan menggunakan Anggaran Pendapatan dan Belanja Negara atau sumber pendapatan lain yang sah.

Sebagaimana halnya masalah yang terjadi di banyak instansi di Indonesia tentang pengelolaan barang/aset negara, penatausahaan barang/aset negara di Balai Litbangkes Banjarnegara masih menemukan sejumlah permasalahan.

Berdasarkan data observasi lapangan, masalah-masalah tersebut dapat diuraikan sebagai berikut:

1. Barang inventaris kantor seringkali dipindahkan tempatkan tanpa adanya komunikasi dengan bagian pengelola penanggungjawab barang. Akibatnya, daftar inventaris barang sering berubah sehingga kesulitan dalam pendataan barang/aset negara di Balai Litbangkes Banjarnegara.

2. Dari sisi Sumber daya, belum tersedianya pegawai yang mengelola secara khusus kegiatan penatausahaan barang milik negara tersebut. Sebagaimana diketahui bahwa setiap Aparatur Sipil Negara atau ASN diangkat dalam tugas pokok dan jabatan yang diatur dalam Peraturan Menteri
Pemberdayagunaan Aparatur Negara dan Reformasi Birokrasi republik Indonesia Nomor 23 Tahun 2018 tentang Jabatan Fungsional Penatalaksana Barang. Meskipun tersedia Peta Jabatan Pejabat Fungsional Analis Barang Milik Negara dan Penata Usaha Barang Terampil, akan tetapi belum ada pegawai yang mengisi jabatan tersebut.

3. Sementara itu, meskipun Kepala Balai Litbangkes Banjarnegara telah memberikan kewenangan penatausahaan BMN pada bagian tata usaha, namun dalam observasi lapangan peneliti masih menemukan ketidaksesuaian antara pelimpahan kewenangan itu dengan realisasi penatausahaan barang di tingkat bawahan atau pengelola teknis BMN.

\section{KAJIAN LITERATUR}

Manajemen strategik merupakan proses atau rangkaian kegiatan pengambilan keputusan yang bersifat mendasar dan menyeluruh, disertai penetapan cara melaksanakannya, yang dibuat oleh pimpinan dan diimplementasikan oleh seluruh jajaran di dalam suatu organisasi, untuk mencapai tujuan. dikatakan bahwa manajemen stratejik adalah kumpulan dan tindakan yang menghasilkan perumusan (formulasi) dan pelaksanaan (implementasi) rencana-rencana yang dirancang untuk mencapai sasaransasaran organisasi.

Pengertian manajemen strategik menurut Nawawi (2003) adalah perencanaan berskala besar (disebut perencanaan strategi) yang berorientasi pada jangkauan masa depan yang jauh (disebut visi), dan ditetapkan sebagai keputusan pimpinan tertinggi (keputusan yang bersifat mendasar dan prinsipil), agar memungkinkan organisasi berinteraksi secara efektif (disebut misi), dalam usaha menghasilkan sesuatu (perencanaan operaional untuk menghasilkan barang dan/atau jasa serta pelayanan) yang berkualitas, dengan diarahkan pada optimalisasi pencapaian tujuan (disebut tujuan strategis) dan berbagai sasaran (tujuan operasional) organsasi. 
Menurut J. David Hunger (Nawawi, 2003) "Strategic management is that a set of managerial decisions and actions that determines the long-run performance of a corporation" dan jika diterjemahkan secara bebas maka manajemen strategik adalah serangkaian keputusan dan tindakan yang menentukan kinerja perusahaan dalam jangka panjang manajerial.

Thomas L. Wheelen (Nawawi, 2003) Manajemen startegik adalah serangkaian keputusan dan tindakan yang menentukan kinerja perusahaan dalam jangka panjang manajerial.

Gregory G Dees (Nawawi, 2003) Manajemen strategik adalah kombinasi dari tiga kegiatan analisis strategi, perumusan strategik dan strategi implentasi.

Dari pengertian manajemen strategi di atas yang cukup luas tersebut menunjukkan bahwa manajemen strategik merupakan suatu sistem yang sebagai satu kesatuan memiliki berbagai komponen yang saling berhubungan dan saling mempengaruhi, dan bergerak secara serentak (bersama-sama) kearah yang sama pula.

Komponen pertama adalah perencanaan strategik dengan unsur-unsurnya yang terdiri dari visi, misi, tujuan dan strategi utama organisasi. Sedangkan komponen kedua adalah perencanaan operasional dengan unsure-unsurnya sasaran dan tujuan operasional, pelaksanaan fungsi-fungsi manajemen berupa fungsi pengorganisasian, fungsi pelaksanaan dan fungsi penganggaran, kebijaksanaan situsional, jaringan kerja internal dan eksternal, fungsi kontrol dan evaluasi serta umpan balik. Disamping itu pengertian manajemen strategik yang telah sebutkan terakhir dapat diambil beberapa kesimpulan yaitu :

1. Manajemen strategik diwujudkan dalam bentuk perencanaan berskala besar dalam arti mencakup seluruh komponen dilingkungan sebuah organisasi yang dituangkan dalam bentuk rencana strategis (Renstra) yang dijabarkan menjadi perencanaan operasional, yang kemudian dijabarkan pula dalam bentuk program kerja dan proyek tahunan.
2. Renstra berorientasi pada jangkauan masa depan.

3. Visi, misi, pemilihan strategi yang menghasilkan strategik induk, dan tujuan strategik organisasi untuk jangka panjang merupakan acuan dalam merumuskan rencana strategi, namun dalam teknik penempatannya sebagai keputusan manajemen puncak secara tertulis semua acuan tersebut terdapat didalamnya.

4. Renstra dijabarkan menjadi rencana operasional yang antara lain berisi program-program operasional termasuk proyek-proyek, dengan sasaran jangka sedang masing-masing juga sebagai keputusan manajemen puncak.

5. Penetapan renstra dan rencana operasi harus melibatkan manajemen puncak karena sifatnya sangat mendasar/prinsipil dalam pelaksanaan seluruh misi organisasi, untuk mewujudkan, mempertahankan dan mengembangkan eksistensi jangka sedang termasuk panjangnya.

6. Pengimplementasian strategik dalam program-program termasuk proyekproyek untuk mencapai sasarannya masing-masing dilakukan melalui fungsi-fungsi manajemen lainnya yang mencakup pengorganisasian, pelaksanaan, penganggaran dan kontrol.

\section{METODE PENELITIAN}

Dalam penelitian kualitatif, metode pengumpulan data adalah upaya untuk membatasi penelitian, dengan cara mengumpulkan informasi melalui wawancara dan observasi serta usaha untuk merancang dan merekam atau mencatat informasi (Maleong. 2011). Dalam penelitian ini adapun metode/teknik pengumpulan data yang digunakan adalah: Observasi adalah salah satu kegiatan penelitian untuk mendapatkan informasi melalui pengamatan langsung. Dalam hal ini peneliti akan terjun langsung kelapangan untk mengunjungi subyek penelitian. Wawancara Mendalam (In-depth Interview) merupakan teknik wawancara dengan cara bertatap langsung antara informan 
dan pewancara, dengan atau tanpa menggunakan pedoman wawancara. Pedoman wawancara dalam wawancara mendalam hanya digunakan sebagai acuan, dan pertanyaan dapat berkembang sesuai dengan kondisi di lapangan. Dokumentasi Menurut Moleong (2011) menyatakan bahwa dokumentasi adalah salah satu metode dalam penelitian kualitatif untuk mendapatkan datadata dari segi konteks. Kajian dokumentasi dilakukan terhadap catatan, foto-foto dan sejenisnya yang berkorelasi dengan permasalahan penelitian. Dokumentasi sendiri bisa berupa film atau bahan tertulis.

Penelitian ini di lakukan selama 5 (empat) bulan mulai pada awal Februari sampai Juni 2021, dengan jumlah informan sebanyak 6 orang yang terdiri dari Kepala Balai Litbangkes sebagai kuasa pengguna barang, Bagian Tata Usaha, Pengelola barang, Pejabat perbendaharaan, Analisis SDM, Pengguna barang serta stakeholder pendukung. Tehnik dalam pengambilan sampel untuk penelitian ini adalah purposive sampling.

\section{HASIL PENELITIAN DAN PEMBAHASAN}

Pemerintah sebagai membuat kebijakan yaitu Peraturan Pemerintah Nomor 27 Tahun 2014 tentang Pengelolaan Barang Milik Negara/Daerah. Pada pasal 3 ayat (1) dituliskan bahwa pengelolaan barang milik negara harus dilaksanakan berdasarkan asas fungsional, kepastian hukum, transparansi, akuntabel, efisien dan kepastian nilai yang berarti pengelolaan barang milik daerah telah memiliki penyempurnaan peraturan agar lebih baik ke depannya.

Berdasarkan tujuan kebijakan tersebut, untuk membuktikan bagaimana pelaksanaan penatausahaan barang milik negara di Balai Litbangkes Banjarnegara, peneliti menggunakan teori George Edward III dengan 4 dimensi, yaitu: komunikasi, sumber daya, desposisi, dan struktur birokrasi.

\section{Aspek Komunikasi}

Model implementasi kebijakan Edward III adalah Top Down, yang berarti dalam dimensi komunikasi fokus utama yang dimaksud adalah transmisi, kejelasan dan konsistensi. Dalam rangka menyamakan persepsi dan langkah secara integral dari semua lembaga dalam penatausahaan barang milik negara, serta untuk meningkatkan pemahaman, pengetahuan, kemampuan dan keterampilan khususnya bagi pengelola barang yang menangani barang milik negara, dilakukan komunikasi kebijakan. Pertemuanpertemuan rutin seperti rapat koordinasi antara pengelola barang milik negara dengan para pejabat pengguna barang milik negara yang ada di lembaga sudah sering dilakukan.

Berdasarkan wawancara dengan beberapa informan untuk Aspek Komunikasi tentang kebijakan penatausahaan BMN diperoleh hasil sebagai berikut :

Jastal S.K.M, M.Si (51 thn) mengatakan "Kebijakan kita mengikuti aturan yang ada ya sudah diatur dari kemenkes, cuma untuk opeasionalnya kita selalu menyampaikan bahwa halhal yang terkait dengan kebijakan untuk saling mengingatkan supaya dilaksanakan" (Wawancara tanggal 19 Mei 2021).

Wisa Erlangga, S.Ap (39 thn) juga mengatakan "terkait dengan kebijakan barang milik negara, penatausahaan dan pengelolaan barang milik negara setahu saya itu dilakukan dikerjakan oleh seorang yang memang punya kopentensi punya keahlian yang sesuai dalam mengerjakan hal tersebut, secara garis besarnya di balai litbangkes banjarnegara sudah berjalan sesuai dengan aturan" (Wawancara tanggal 18 mei 2021).

Danang Damar Binanto (32 thn) mengatakan "jadi Kebijakan Penatausahaan BMN itu merupakan salah satu siklus dalam pengelolaan BMN, dasar hukumnya adalah PMK 181 tahun 2016 bertujuan untuk mewujudkan tertib administrasi dan mendukung tertib pengelolaan BMN. Kemudian Ruang 
lingkup penatausahaan BMN meliputi kegiatan pembukuan, inventarisasi, dan pelaporan BMN,

Sasaran penatausahaan adalah semua barang yang dibeli atau diperoleh atas beban APBN" (wawancara tanggal 30 April 2021)

$$
\text { Kepala Balai Litbangkes }
$$

Banjarnegara dan pengelola barang milik negara yang diberikan tanggungjawab diharuskan tegas terhadap tindakan yang dilakukan oleh pegawai tersebut. Tegas yang dimaksud di sini adalah memberikan sanksi atau teguran terhadap tindakan tersebut. Dalam hal komunikasi, sikap tersebut sangat mempengaruhi tujuan dari proses komunikasi yakni mewujudkan penatausahaan barang/ aset negara sesuai dengan amanat undang-undang atau sebagaimana yang diatur dalam Peraturan Pemerintah No. 27 Tahun 2014. Meskipun masalah tersebut sudah sering disampaikan dalam pertemuan, namun koordinasi yang intens antara kepala kantor selaku Kuasa Pengguna Barang, pengelola barang kepada semua pegawai-pegawai sebagian kurang mendapat respon. Akibatnya, para pegawai kurang memahami maksud dan tujuan kebijakan tersebut.

\section{Aspek Sumber daya}

Sumber daya adalah sarana maupun prasarana, baik hayati maupun non hayati, termasuk juga di dalamnya sumber daya manusia, yang terdapat dalam suatu karakteristik wilayah tertentu. Namun, dalam hal ini sumber daya diartikan sebagai sarana dan prasarana yang menunjang sebuah kebijakan, termasuk di dalamnya sumber daya manusia sebagai pelaksana kebijakan.

Berdasarkan wawancara dengan beberapa informan untuk Aspek Sumber Daya terkait tanggungjawab terhadap pengelolaan menejemen penatausahaan BMN di Balai Litbangkes Banjarnegara sebagai berikut :
Wisa Erlangga, S.Ap (39 thn) mengatakan "kepala balai selaku kuasa pengguna barang tapi ketika itu di distribusikan ke tingkat bawah ada kasubag tata usaha dan yang paling akhir itu harusnya adalah pranata pengelolaan $B M N$ intinya pengelola $B M N$ " (Wawancara tanggal 18 mei 2021).

Eti Supeni,SE juga mengatakan "secara otomatis ya pimpinan selaku kuasa pengguna barang karena beliau sebagai pimpinan harus mengetahui seluk beluk BMN tapi disini dibantu oleh petugas BMN yang mengelola BMN tersebut dengan agar bisa dikeloa dengan baik dan benar" (wawancara tanggal 5 Mei 2021).

Menurut para ahli Van meter dan Van Horn dalam Nugroho (2011) menjelaskan bahwa kajian implementasi kebijakan perlu dukungan sumber daya manusia (human resources) maupun sumber daya non manusia (non-human resources). Senada dengan hal tersebut, menurut pendapat Edward III, dalam Budi Winarno (2012) bahwa secara konseptual Sumber daya diartikan sebagai isi kebijakan yang dapat dikomunikasikan secara jelas dan konsisten, tetapi apabila implementor kekurangan sumber daya untuk melaksanakan kebijakan, diyakini pelaksanaan kebijakan tersebut tidak berjalan secara efektif. Terlebih lagi kualitas sumber daya masih lemah justru berdampak pada kurang optimalnya pengimplementasian kebijakan tersebut.

Dari wawancara diatas bisa disimpulkan bahwa faktor sumber daya dalam implementasi kebijakan penatausahaan barang milik negara di Balai Litbangkes Banjarnegara masih belum memadai, baik menyangkut kebutuhan sumber daya manusia, penataan, maupun sumber daya informasi dan kewenangan.

Sumber daya manusia pada setiap lembaga / kantor terutama pengelola barang yang secara teknis 
mengurusi penataan barang/ aset milik negara, secara kuantitas dan kualitas masih belum memadai. Ini terlihat bahwa saat ini di Balai Litbangkes Banjarnegara memiliki 1 (satu) orang pengelola barang milik negara,

\begin{tabular}{|c|c|c|c|c|c|c|}
\hline No & xasen & $\begin{array}{l}\text { Thlox } \\
\text { micilfus }\end{array}$ & Learis! & SERTIFIKAT & tancast & ${ }_{\mathrm{SC}}$ \\
\hline 1 & 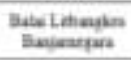 & 200 & Menparase & Putase 72 & $20 \operatorname{sen} 2 m$ & 230 \\
\hline 2 & 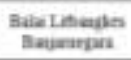 & soir & Senerepan & haw s. 74 & as reterum 2090 & 2,005 \\
\hline \multicolumn{6}{|c|}{ Sumiat } & 5.29 \\
\hline
\end{tabular}

sementara luas kantor sekitar 5,293 m2 dengan nilai nominal keseluruhan barang/aset yang ada berdasarkan data Aplikasi SIMAK BMN per 31 Desember 2020 yaitu Rp22.871.838.429.

Data Kepemilikan tanah

Sumber:Balai Litbangkes Banjarnegara,2021

Dengan beban kerja dan tanggung jawab yang berat idealnya setiap lembaga/kantor harus memiliki minimal 2 (dua) orang pengelola barang atau disesuaikan kebutuhan yang diperlukan. Disamping itu, pengelola barang milik negara juga harus mempunyai pengetahuan dan keahlian dasar dalam penatausahaan barang milik negara. Berdasarkan temuan yang ada, Balai Litbangkes Banjarnegara masih memiliki masalah dalam hal sumber daya manusia atau pengelola teknis barang milik negara.

Kurang maksimalnya kuantitas dan kualitas pengelola barang milik negara di Balai Litbangkes Banjarnegara mengakibatkan sulitnya kebijakan penatausahaan barang/aset diterapkan dengan baik di lingkungan tersebut. Jumlah pengelola barang milik negara yang hanya 1 (satu) orang sangatlah sulit bahkan tidak mungkin mengurus barang/aset yang tidak bergerak dengan luas wilayah seperti itu, apalagi dengan barang/aset bergerak. Pengelola barang milik negara sulit melakukan koordinasi keseluruh penanggung jawab ruangan, sementara itu juga fungsi lain dari pengelola barang milik negara adalah melakukan pemeliharaan dan perawatan terhadap barang/aset milik negara tersebut. Untuk mengontrol pergerakan/ perpindahan barang/aset ketempat lain yang biasa dilakukan oleh pengguna barang milik negara dengan hanya seorang diri adalah mustahil, sehingga koordinasi tidak berjalan dengan baik.

\section{Aspek Disposisi} pelaksana kebijakan dalam melaksanakan suatu kebijakan yang telah ditetapkan sebelumnya oleh para implementor. Pengelola barang milik negara di Balai Litbangkes Banjarnegara merupakan pelaksana kebijakan yang memiliki keinginan dan berkecenderungan untuk mau dan terus mengimplementasikan kebijakan penatausahaan barang/aset milik negara sesuai dengan amanat Undang-Undang dan Peraturan Pemerintah Nomor 27 tahun 2014 tentang penatausahaan barang/aset milik negara. Namun demikian, sikap ini perlu juga didukung oleh seluruh pengguna barang/aset negara menjadi sebuah komitmen bersama yang mencerminkan bahwa disposisi dalam impelementasi kebijakan penatausahaan barang/aset negara adalah penting dan strategis.

Berdasarkan wawancara dengan beberapa informan untuk Aspek Disposisi tentang komitmen aparatur kebijakan dalam pengelolaan menejemen penatausahaan BMN diperoleh hasil sebagai berikut :

Menurut Danang Damar Binanto (32 thn) pengelola BMN KPKNL Purwokerto mengatakan bahwa: "sebuah komitmen bersama yang mencerminkan bahwa disposisi dalam impelementasi kebijakan penatausahaan barang/aset negara adalah penting dan bersifat strategis. Komitmen yang tinggi dalam melaksanakan kebijakan penatausahaan barang negara merupakan gambaran sikap aparatur negara yang menjunjung tinggi azas-azas dalam penatausahaan barang milik negara" (wawancara tanggal 30 April 2021).

Wisa Erlangga, S.Ap (39 thn) mengatakan "sudah ada komitmen, 
motivasi untuk melakukan tugas tambahan tersebut sebagai petugas pengelola BMN, dilihat dari pekerjaan BMN bisa selesai dan berjalan sesuai seperti pendistribusian BMN, perbaikan aset yang rusak, proses PSP, lelang dan juga revaluasi BMN di KPKNL Purwokerto, dengan adanya komitmen tersebut juga tahun 2019 menjadi BMN terbaik itu sudah merupakan bukti, komitmen serta motiasi meskipun belum ada pegawai fungsional barang tapi sudah mau dan bisa untuk mengelola BMN meskipun keteteran" (Wawancara tanggal 18 mei 2021).

Dari penjelasan tersebut di atas menunjukkan bahwa komitmen dan motivasi bersama baik pimpinan sebagai kuasa pengguna barang dan juga yang bertanggung jawab mengatur bawahannya dalam mendukung kebijakan penatausahaan barang/aset milik negara di Balai Litbangkes Banjarnegara sudah berjalan dengan baik. Komitmen tersebut dapat dilihat dari tindakan atau upaya pimpinan dalam meningkatkan kualitas sumber daya manusianya walaupun masih rangkap jabatan.

\section{Aspek Struktur Birokasi}

Birokrasi merupakan salah satu badan yang paling sering bahkan secara keseluruhan menjadi pelaksana kebijakan. Struktur organisasi yang mengimplementasikan kebijakan memiliki pengaruh yang signifikan terhadap implementasi kebijakan. Dalam melaksanakan kebijakan penatausahaan barang/aset negara pengelola barang milik negara sebagai pihak yang bertanggung jawab dalam penataan barang tersebut berada dibawah Kepala Sub Bagian Tata Usaha.

Kepala Sub Bagian Tata Usaha membawahi langsung dalam penatausahaan barang milik negara. Dalam penelitian ini bahwa bagian pengelolaan barang milik negara pada Balai Litbangkes Banjarnegara sudah memiliki beberapa Standar Operasional
Prosedur (SOP). Standar Operasional Prosedur (SOP) dibutuhkan sebagai petunjuk pelaksanaan penatausahaan barang/aset milik negara akan tetapi dalam pelaksanaanya belumlah maksimal. Dalam PP No.27 tahun 2014 sangat jelas mengamanatkan agar pengelola barang milik negara diwajibkan membuat petunjuk teknis hal-hal yang berkaitan dengan kegiatan penatausahaan barang milik negara, yakni pendataan, inventarisasi, dan pelaporan, juga termasuk didalamnya mekanisme pengadaan barang, pelelangan barang, hibah, kontrak barang, penghapusan barang dan seterusnya.

Berdasarkan wawancara dengan beberapa informan untuk Aspek Struktur Birokrasi terkait Standar Operasional Prosedur (SOP) tentang pengelolaan menejemen penatausahaan barang milik negara sebagai berikut :

Andri Wahyu Prasetyo, S.Sos, M.Si (31 thn) mengatakan "kebetulan saya juga sebagai ketua tim penyusun SOP administrasi pemerintahan di Balai litbangkes Banjarnegara, kalau saya lihat sudah ada SOP cuma pada pelaksanaanya ini secara dokumen sudah tertib sudah terlaksana tapi ketika pelaksanaan dilapangan ini yang masih dalam catatan, seperti DIR yang butuh di update. Saran masih perlu diperbaiki lagi" (Wawancara tanggal 22 April 2021).

Eti Supeni, SE (50 thn) menjelaskan bahwa: "Standar Operasional Prosedur (SOP) secara umum sudah ada tapi secara umum belum maksimal, karena keterbatasan sumber daya manusia karena petugas barang milik negara itu bercabang cabang dalam artian tidak hanya mengelola barang milik negara saja tapi di keuangan nah disitu ketika terjadi penumpukan kinerja, Standar Operasional Prosedur (SOP) tidak berjalan dengan baik" (wawancara tanggal 5 Mei 2021). 
Menurut Danang Damar Binanto (32 thn) pengelola BMN KPKNL Purwokerto mengatakan bahwa: "Peraturan Pemerintah No.27 tahun 2014 sangat jelas mengamanatkan agar pengurus /pengelola BMN diwajibkan membuat petunjuk teknis seperti Standar Operasional Prosedur (SOP). hal-hal yang berkaitan dengan kegiatan penatausahaan BMN, yakni pendataan, inventarisasi, dan pelaporan, juga termasuk didalamnya mekanisme pengadaan barang, pelelangan barang, hibah, kontrak barang, tahap terakhir adalah penghapusan barang" (wawancara tanggal 30 April 2021).

Kurangnya perhatian, monitoring serta evaluasi dari kepala dalam hal ini atasan lansung untuk mengikutsertakan pengelola barang milik negara dalam pelatihan ataupun pertemuan penatausahaan barang/aset negara salah satu faktor utama sehingga Standar Operasional Prosedur (SOP) tersebut belum berjalan secara maksimal. Kurangnya pengetahuan pengelola barang milik negara terkait dengan penatausahaan barang milik negara menjadi faktor penghambat adanya Standar Operasional Prosedur SOP yang dimaksud. Padahal keberadaan Standar Operasional Prosedur (SOP) sangat penting dan mendesak, disamping kemampuan sumber daya manusiannya agar penataan barang/aset milik negara berjalan efektif.

\section{SIMPULAN DAN SARAN}

Efektifitas implementasi kebijakan penatausahaan barang milik negara pada Balai Litbangkes Banjarnegara belum berjalan dengan baik. Dari 4 (empat) dimensi yang diteliti dengan model implementasi kebijakan George Edward III seluruhnya (komunikasi, sumber daya, disposisi, dan struktur birokrasi) belum berjalan dengan baik antara fakta lapangan dengan teori yang digunakan, dan Peraturan Pemerintah Nomor 27 tahun 2014 tentang Pengelolaan Barang Milik
Negara/Daerah. Adapun penerapan keempat dimensi tersebut dapat terlihat melalui aspek :

1. Komunikasi, pelaksana kebijakan kurang memahami tujuan dari kebijakan penatausahaan barang/aset milik negara.

2. Sumber Daya, tidak adanya jabatan fungsional pengelola barang yang diposisikan di bagian pengelolaan Barang milik negara (BMN) dan kualitas Sumber Daya Manusia yang masih kurang.

3. Disposisi, kurangnya komitmen bersama dalam memahami tujuan dari impelementasi kebijakan penatausahaan barang/aset negara.

4. Struktur Birokrasi, sudah terdapat Standar Operasional Prosedur (SOP) di bagian pengelolaan BMN sebagai pedoman dalam penatausahaan barang milik negara akan tetapi dalam implementasinya masih sangat kurang.

\section{SARAN}

Dalam penulisan skripsi ini, peneliti ingin memberikan saran terhadap pembaca, dengan model implementasi kebijakan George Edward III sebagai berikut :

1. Dalam hal komunikasi, yaitu pemerintah dalam hal ini pembuat kebijakan melakukan sosialisasi secara rutin tentang tujuan kebijakan penatausahaan barang/aset negara di semua Lembaga termasuk di Balai Litbangkes Banjarnegara sebab selama ini dianggap belum maksimal, agar implementasi kebijakan bersifat Top Down tersebut berjalan efektif.

2. Dalam hal sumber daya, yaitu :

a. Penambahan Aparatur Sipil Negara yang uraian jabatanya di bidang pengelolaan barang milik negara sesuai dengan kebutuhan yang diperlukan dengan mempertimbangkan keefektifan pelaksanaan kebijakan tersebut. Mengingat yang mengurusi barang/aset negara hanya ada 1 orang yang masih rangkap jabatan sementara barang/aset negara yang 
dimiliki jumlahnya tidak sedikit dan bernilai tinggi.

b. Memberikan pelatihan-pelatihan peningkatan kemampuan dan ilmu mengelola barang milik negara dalam penatausahaan barang/aset negara sebab selama ini dirasakan belum ada sehingga masalah seperti Daftar Barang Ruangan (DBR) bisa disajikan benar dan update baik dari keberadaan barang dan juga tahun yang sesuai.

3. Dalam hal disposisi, yaitu Kepala Balai Litbangkes Banjarnegara harus terus melakukan koordinasi dengan pembuat kebijakan tentang efektifitas pelaksanaan implementasi kebijakan penatausahaan barang/aset di lingkungan kerjanya, serta terus mengawasi pelaksanaan kebijakan tersebut, sebab yang dirasakan selama ini masih kurang.

4. Dalam hal struktur birokrasi, yaitu Standar Operasional Prosedur (SOP) tentang penatausahaan barang/aset negara pada bagian pengelolaan barang milik negara di Balai Litbangkes Banjarnegara yang sudah ada untuk dilaksanakan yang sampai saat masih belum maksimal untuk pelaksanaanya dan terdapat monitoring/pengawasan dari atasan langsung atau kepala kantor

\section{DAFTAR PUSTAKA}

Anggara, Sahya. 2014. Kebijakan Publik, Cetakan 2. ISBN: 978-979-076-487-3. Bandung: Pustaka Setia

Akib, Haidar. 2010. Implementasi Kebijakan: Apa, Mengapa, dan Bagaimana. Jurnal Administrasi Publik. Vol 1 No. 1. DOI: https://doi.org/10.26858/jiap.v1i1. $\underline{289}$

Nawawi, 2003 Manajamen Sumber Daya Manusia untuk Bisnis yang Kompetitif. Gajah Mada University press. Yogyakarta

Peraturan Menteri Kesehatan Republik Indonesia Nomor 9 Tahun 2018. Tentang Pedoman Pengelolaan Barang milik negara Di Lingkungan Kemenkes
Peraturan Menteri Keuangan Republik Indonesia Nomor 181 Tahun 2016. Tentang Penatausahaan Barang milik negara

Peraturan Pemerintah Republik Indonesia Nomor 27 Tahun 2014. Tentang Pengelolaan Barang milik negara/daerah

Vebrianto, Avib. 2016. Implementasi Kebijakan PenatausahaanBarang/Aset Negara Pada Balai Penelitian dan Pengembangan Pengendalian Penyakit Bersumber Binatang Donggala 